\title{
UPBRINGING AS A PROCESS IN PRIMARY EDUCATION
}

\section{Zukhra Umarova}

Teacher, Department “Primary Education”, Chirchik State Pedagogical Institute Of Tashkent Region, Uzbekistan

\section{ABSTRACT}

The article analyzes the foundations and processes of upbringing in primary education and provides guidelines on this issue.

KEYWORDS: - Education, upbringing, primary, process, content, means, type, knowledge, habit, approaches, skill, experience, theory, practice.

\section{INTRODUCTION}

The content of upbringing process in primary education. The process of upbringing is continuous and integral. Therein word "process" implies constantly fulfilling pedagogical measures. In this sense, the upbringing process in primary education is the most important and multifactorial phenomenon. Because the main task of pedagogy is the comprehensive education of the personality of students aged 7-11. It should be noted that the primary impact on carry out upbringing process in primary education is as follows:

- the effect of environment;

- the impact of vital needs;

- the impact of important values of society;
- g) family influence;

- public influence;

- the influence of groups of children;

- y) the influence of art;

- j) the influence of mass media [1].

Such a wide range of influences on the process of educating primary school students can be both positive and negative. Therefore, primary school teachers are required to monitor the positive effects of these factors, in order to mitigate negative effects. For instance, the impact of the environment on primary school students is actually positive, but as a result of students' misperception the environment, its impact 
CURRENT RESEARCH JOURNAL OF PEDAGOGICS 2(8): 127-131, August

2021 DOI: https://doi.org/10.37547/pedagogics-crjp-02-08-27

ISSN 2767-3278

(C)2021 Master Journals

\section{Crossref dof 81 Google}

Accepted $26^{\text {th }}$ August, 2021 \& Published 31 th August, 2021

becomes negative. Similarly, the abovementioned influencing factors should be controlled. For example, in Uzbekistan, the influence of family on upbringing process is a priority. In process of further development and as a result of the composition of private property, the negative impact of the family on the upbringing of primary school students is growing. These include a child's interest in property, pride in his parents' wealth, and arrogance among his peers. That is why we are in favor of correcting the influence of family in the process of educating primary school students. At the same time, it is important that the influence of exemplary families is perceived as positive and the influence of troubled families as negative.

In our approach, the influence of teachers and the school community in the process of upbringing primary school students should be given priority. Because this group is fulfilling the demands and necessities of the society towards upbringing. In this sense, the content of education in primary education represents the targeted social development and maturity of individuals aged 7-11 [2]. In this case, any influence is directed to the realization of the purpose of education.

The content of the educational process in primary education is determined by the physical, mental, spiritual and aesthetically healthy development of individuals aged 7-11. Therefore, the purpose of this process is the social transformation of the taking shape individual and the use of various educational tools. It is based on ideal ideas, high values and noble goals. This issue is especially important in the education of primary school students. What is clear is that every parent or community wants every child to come of age as a brought up individual. However, as a result of the misuse of educating tools, activities, and factors, not every child grows up to the expected level of personality. In this regard, we see way for primary school students to achieve the expected outcome of the educational process in two cases: first, the rights and responsibilities of the school community should be a priority in the education of students aged 7-11; secondly, in a democratic society, it is impossible to bring up primary school students as one hundred percent educated individuals, in this case achieving the expected level of education of 80-85 percent of primary school students is a high indicator. All this shows that the process of education in primary education is a "living" phenomenon.

Educational tools in primary education. In pedagogical practice, the mental, moral, labor, physical and aesthetic upbringing of students is firmly accepted. Today, environmental education, art education and religious education are added to this process. Regardless of the breadth of education, the main issue is the acceptability of educational tools and their proper use. The abundance of educational tools in the modern primary education process is noteworthy. The abundance of educational tools, in our approach, distracts from the educational purpose and undermines the effectiveness of education. Therefore, it is necessary to choose the most optimal and effective means of education in the education of primary school students. Here we mention the most acceptable of such educational tools:

- educate through the teaching of academic subjects;

- Targeted and purposeful education of students through the subject of "Education";

- educate by a means of spiritual activities;

- educate through art and literature;

- educate by demonstrating past and thinkers as an edifying [3].

The role and importance of these educational 
CURRENT RESEARCH JOURNAL OF PEDAGOGICS 2(8): 127-131, August

2021 DOI: https://doi.org/10.37547/pedagogics-crjp-02-08-27

ISSN 2767-3278

(C)2021 Master Journals

\section{Crossref doi) 81 Google}

Accepted $26^{\text {th }}$ August, 2021 \& Published 31 th August, 2021

tools in the education of primary school students is great.

As mentioned above, in the new conditions of Uzbekistan, it is planned to carry out the educational process in accordance with the "Concept of continuous spiritual education." In this sense, according to this concept, the task of educating primary school students is based on the following qualities:

- formation of students' sense of devotion to the Motherland;

- instilling in students an entrepreneurial spirit;

- development of willpower in students;

- g) formation of ideological immunity in students;

- instilling in students the ability to be kind;

- formation of responsibility in students;

- y) building tolerance skills in students;

- j) formation of legal culture of students;

- h) teaching students to think innovatively;

- teaching students to be hardworking.

Attention is drawn to the formation of 10 qualities and abilities in primary school students. All this requires the use of educational tools based on real conditions and opportunities in the educational process.

In recent years, the positive impact of means of cultural travel in the targeted education of primary school students in Uzbekistan is obvious. According to it, primary school students are introduced to our most ancient monuments, cities and traditions in the form of excursions. As a result of such an educational tool, students are expected to develop skills such as patriotism, nationalism, national pride and loyalty.

The educational tools used in the upbringing process of primary school students should be convenient, easy and rich in features with a wide range of possibilities.

Types of upbringing in primary education. As we know, there are many types of bringing up that can be done in primary education. At present, in the conditions of the new Uzbekistan, it is important to implement the following types of education in primary education:

1. Civic education. According to this upbringing, students aged 7-11 should be brought up in the spirit of devotion to their family, Motherland, national values, people and humanity. In the context of Uzbekistan in civic education is divided in accordance with the constitutional and private rights of the individual. As a prospective citizen, primary school students should have an understanding of their civil rights, duties, and responsibilities.

2. Economic education. According to this education, a sense of honest diligence should be formed in the minds of 7-11-year-olds, and it is on the basis of this ability that the family, society, state and country can be rich and prosperous. To do this, it is necessary to pay attention to the formation of qualities in primary school students, such as thrift, self-sufficiency, patience, and the absence of such vices as wastefulness, laziness, cunning. At the same time, the rational use of opportunities of new subject of "Education" in our country will give expected results.

3. Ecological education. According to this type of upbringing, the formation of natureloving qualities in 7-11-year-olds and their compassionate attitude to natural phenomena should be included. For this purpose, it would be expedient for primary school students to be widely acquainted with the animal and plant world.

4. Legal education. According to this type of education, pupil aged 7-11 are given an idea of 
their rights, duties and responsibilities. Observations depict that primary school students understand their rights very early, relying on a sense of self "I", but it is difficult to understand the duties and responsibilities that are an integral part of this right. Therefore, the main task of legal education in primary education is to teach students the rights, duties and responsibilities of the individual.

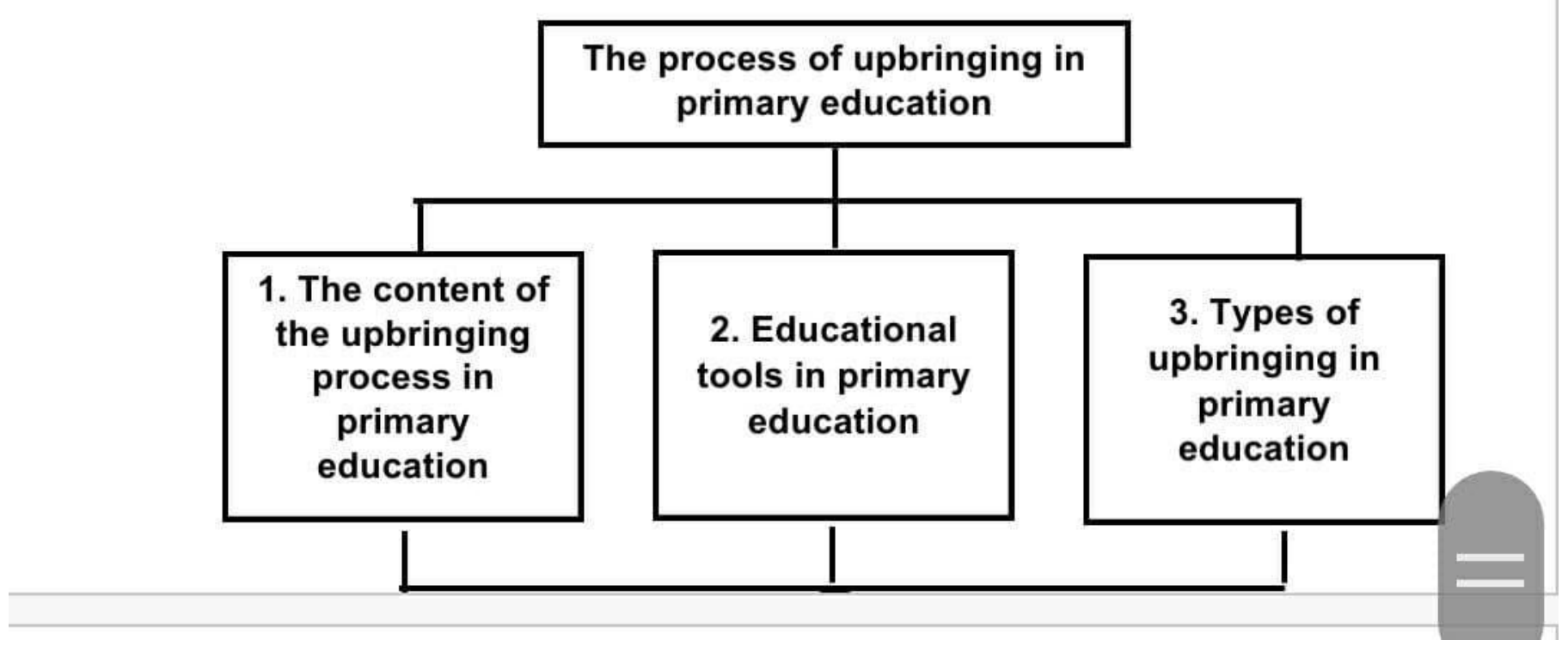

\section{THE EDUCATIONAL PROCESS IN PRIMARY EDUCATION}

Thus, the process of education in primary education is based on the most important goals, means and types of pedagogy.

\section{REFERENCES}

1. Умарова М.Теория и история педагогики. -Т.:"Чўлпон".2018.-с 202

2. Педагогик атамалар луғати. Р.Жўраев ва бошқ. - Т. “Фан”. 2008.49-бет

3. Умарова 3.А. Бошланғич таълимда педагогик жараён. // Муғаллим хам узликсиз билимлендириў. Илмийметодик журнал. ISSN 2181-7138. №1 2021 й. 70-74-бет.

4. Mamadaliyev K.R., Jabborova O.M., Umarova Z.A., Abdullaeva B.P. Creation of a New Generation of Teaching Literature -A Requirement of Modernity // SCOPUS International Journal of Psychosocial Rehabilitation, Vol. 24, Special Issue 1, 2020.

5. Жабборова Онахон Маннаповна, 
CURRENT RESEARCH JOURNAL OF PEDAGOGICS 2(8): 127-131, August

2021 DOI: https://doi.org/10.37547/pedagogics-crjp-02-08-27

ISSN 2767-3278

(C)2021 Master Journals

Crossref do: 81 Google

Accepted $26^{\text {th }}$ August, 2021 \& Published 31 th August, 2021

Ташпулатова Дилором Мукимовна, Бошланғичсинфўқитувчиларигақўйилад иганталаблар. Academic research in educational sciences, Issue 3,2021 , pp 575-5827.

6. Жабборова О.М., Умарова 3.А. Тарбия фанини кластер усулида ўқитишдапедагогикконфликтларнибарт арафэтиш. Academic research in educational sciences, Issue 1, 2021, pp 582587.

7. 7.Наримбетова З.А. УЧИТЕЛЬНРАВСТВЕННЫЙ ПРИМЕР ДЛЯ УЧЕНИКА. ACADEMIC RESEARCH IN EDUCATIONAL SCIENCES VOLUME 2

8. Кузманова Г.Б., Н.А.Бекетов Use of Historical Materials In Teaching Mathematics In Continuous Education. The american journal of social science and education innovations, Volume 2 Issue 9, 2020, ISSN 2689-100X, 2(09), 531537.12.14.

9. Кузманова Г.Б.UMUMIY O’RTA TA'LIM MAKTABLARIDA MATNLI MASALALARNING TA'LIMIY AHAMIYATI. ACADEMIC RESEARCH IN EDUCATIONAL SCIENCES, 2(3), 1154-1159

10. Abdullaeva B.P. Corruption in the field of education: assessments and ways to address. “Тенденции и перспективи развития науки и образования в условиях глобализации".Международной научно-практической интернетконференции. г.Переяслав, Украина.2020 год 30

11. Abdullaeva B.P. Babaraximova B.P. Pardaev B.P.Using information and communication technologies in teaching process of various primary European Journal of Research and Reflection in Educational Sciences, 8 (10), 67-70. Progressive
Academic

Publishing,

UKwww.idpublications.org 14.10.2020.

12. Abdullaeva B.P. Abdullaev F.T. Organization Of Swimming Lessons In Preschool Institutions THE AMERICAN JOURNAL OF SOCIAL SCIENCE AND EDUCATION INNOVATIONS. JULY 2020[ TAJSSEI]322ISSN (e):2689-100X DOI: https://doi.org/10.37547/tajssei/Volume0 2Issue 07-423.

13. Abdullayeva, B.P., \& Babaraximova, B. P. (2020). MAKTABGACHA TA'LIM MUASSASASIDA FUTBOL DARSLARINI TASHKIL ETISH METODIKASI. Academic Research in Educational Sciences http://ares.uz/jurnallar-sahifasi/ares-vol-1no-3-20204.

14. Abdullaeva B.P. ACADEMICIA: An International Multidisciplinary Research Journal https://saarj.com ORGANIZATION AND METHODOLOGY OF CONDUCTING FOOTBALL LESSONS IN A PRESCHOOL INSTITUTION 650-655 10.5958/22497137.2021.00098. 